\title{
IS THE COARSE-GRID GLOBAL CLIMATE MODEL A USEFUL TOOL FOR REGIONAL PALEOCLIMATE RECONSTRUCTION?
}

\author{
IZABELA SZUMAN \\ Adam Mickiewicz University, Institute of Geoecology and Geoinformation, Poznań, Poland \\ BARTOSZ CZERNECKI
}

Adam Mickiewicz University, Institute of Physical Geography and Environmental Planning, Poznań, Poland

Manuscript received: January 28, 2011

Revised version: March 01, 2011

SzumAn I., Czernecki B., 2011. Is the coarse-grid Global Climate Model a useful tool for regional paleoclimate reconstruction? Quaestiones Geographicae 30(1), Bogucki Wydawnictwo Naukowe, Poznań, pp. 115-121, 4 Figs. ISBN 978-83-62662-39-5. ISSN 0137-477X. DOI 10.2478/v10117-011-0011-3.

\begin{abstract}
AвSTRACT. This study considers the climate at the time of the Weichselian ice sheet maximum in Central Europe, especially in Poland, in respect of the NASA Educational version of Global Climate Model (EdGCM). The final results of the EdGCM simulations for the Last Glacial Maximum (LGM) are presented here and these have been analysed to determine whether or not they are useful for regional scale modelling; the problem being that, in a global climate model, both horizontal and vertical grid resolution is very low. Also, an attempt has been made to define the role of the ice megalobe which, in terms of the numerical coarse-grid model,covered the northern parts of Germany and Poland. The broad details of the climate during the Weichselian are defined and our results are compared with previous opinion. The influence of ice megalobe on regional climate is demonstrated and it is also concluded that a coarse-grid global climate model could be a helpful tool in a regional climate recognition. However, whether at a regional or local scale, it is recommended that a specially-configured version of a Regional Climate Model (RCM) based on Global Climate Model (GCM) boundary conditions be used in similar reconstructions.
\end{abstract}

KeYWords: Weichselian ice sheet, LGM, climate conditions, coarse-grid model, Poland

Izabela Szuman, Adam Mickiewicz University, Institute of Geoecology and Geoinformation, Dzięgielowa 27, 61-680

Poznań, Poland, e-mail: szuman@amu.edu.pl

Bartosz Czernecki, Adam Mickiewicz University, Institute of Physical Geography and Environmental Planning, Dzięgielowa 27, 61-680 Poznań, Poland, e-mail:nwp@amu.edu.pl

\section{Introduction}

The Last Glacial Maximum (LGM), the time when the Weichselian ice sheets extended furthest south, took place ca. $21 \mathrm{ka}$ BP i.e. when sea level was at its lowest: 22-19 ka BP (Yokohama et al. 2000). Huge ice caps over the northern parts of North America, Antarctic and Eurasia forced global climate changes. Ice sheets are a one of major forces controlling influence on climate (Kutzbach \& Webb III 1993). At that time, an ice megalobe (Kasprzak 2003) of the Weichselian ice 
sheet covered the eastern part of Germany and western-central Poland (Fig. 1) and it is inevitable that such an orographic barrier would influence climate at some scale.

The aim of our project was to employ Educational Global Climate Model (EdGCM) simulations in order to examine whether they might be useful for regional scale modelling. The authors also tried to define the role of the ice megalobe in the southern flanks of the Weichselian ice sheet in terms of a coarse-grid numerical model. The EdGCM was chosen for this case study because it was easy to install and relatively simple to use, having all necessary components for processing, even by non-atmospheric-science specialists. However, the authors recognise, that the model was not specially designed for this purpose, so our conclusions necessarily focus on the notion of using GCM (Global Climate Model) in paleoclimate research rather than whether the EdGCM is statistically accurate.

The climatological data obtained from our model simulation were compared to paleoclimate proxies from existing literature. The authors regard dunes and windpolished boulders as a paleowind indicators and permafrost features for temperature and precipitation.

Previously global climate has usually been modelled only at a very low horizontal and vertical grid resolution and at a regional scale, as in our project, the study area has typically included very few grid cells. Thus the results for relatively small areas are unreliable, owing to small amount of information given by a dynamical model; nor can the results simply be represented by linear

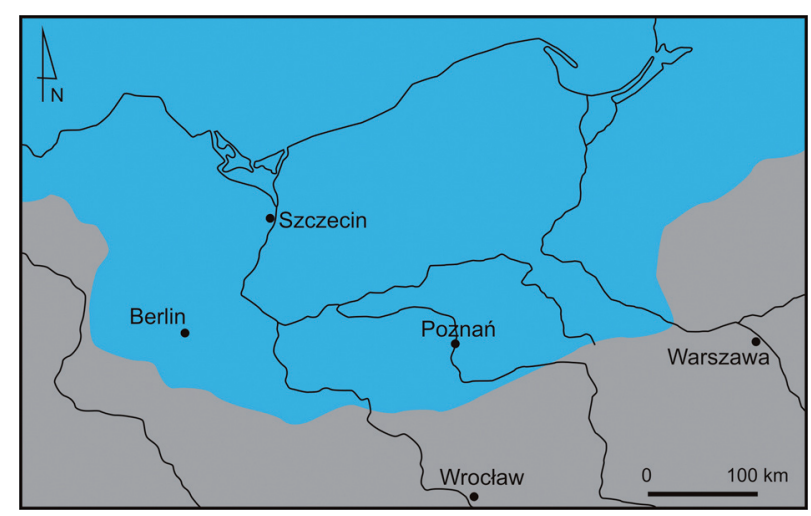

Fig. 1. Maximum extent of the Weichselian ice sheet - blue, (after Kasprzak 2003) interpolation methods as is the norm in previous studies.

This study focusses on climatic situations with regard to Polish territory, but our interpretations are also placed in a wider Central European context. The simulation of sea level pressure is presented in respect of the entire northern part of Atlantic Ocean and Europe, because of the fact, that low and high pressure areas must be interpreted in synoptic scale (i.e., for whole European area), whereas surface air temperature, precipitation and winds only for the regional scale, between ca. $47^{\circ}-57^{\circ} \mathrm{N}, 10^{\circ}-30^{\circ} \mathrm{E}$.

\section{Numerical climate model settings and techniques used}

EdGCM is the NASA model, developed at the Goddard Institute for Space Studies, Columbia University. The EdGCM provides a researchgrade GCM with a user-friendly graphical interface. The 30-day trial version is available online (http://edgcm.columbia.edu) for MacOS X and Windows operating systems and permits the user to run several simulations of both paleoclimates and future climates. However, even the full version has no access to a source code. In contrast to the more technically advanced command line Unix models, EdGCM's menu lets users who are unfamiliar with dynamical modelling techniques, run one of case study simulations without needing to go through sophisticated preprocessing, model run and postprocessing steps.

In preprocessing, the basic initial geographic conditions (i.e., land mass distribution, topography, vegetation distribution) are set at a grid resolution appropriate for the model. Whereas in this particular model, it is not possible to choose static data different from those prepared by EdGCM's authors, in more complex models, it is quite a common procedure. Lack of such an option in the EdGCM reflects the model's simplicity; however, starting the simulation with only one possible default selection has the consequences that the user has no influence on most of the initial conditions. Such a solution guarantees a correct assimilation of data, whereas, in many dynamical models, it may often be a reason for 
compilation errors. For example, users who want to simulate paleoclimates in the EdGCM programme can choose some several sets of values for greenhouse gases, the Earth's orbit or sea level appropriate to the period of interest.

In one of case studies prepared in the model the reconstruction of the paleoclimate for the LGM was based on the scheme of Chandler et al. (2005). This simulation is based on nine vertical layers with horizontal grid resolution over $8^{\circ}$ of latitude and $10^{\circ}$ longitude. The sea surface temperatures built into the simulation are those specified in the CLIMAP project; ice sheet distribution was derived from Peltier et al. (1994). The implied sea level is lower than of the present day by $120 \mathrm{~m}$, while Earth's orbital configuration is taken as that at the present. The model includes $\mathrm{CO}_{2}$ at a level of $200 \mathrm{ppm}$ and the rest of trace gases at: 0.4 ppm $\mathrm{CH}_{4^{\prime}} 0.2754$ ppm $\mathrm{N}_{2} \mathrm{O}$ (all preindustrial values).

The climatic condition in the area of interest were estimated for a 10-year simulation period. Using the EdGCM Visualization Application (EVA), which is based on the Interactive Data Language (IDL) engine, and Panoply software for creating and analysing visualisation of meteorological standard files (i.e. network Common Data Form, NetCDF; Rew et al. 1993), this was further divided into monthly and seasonal intervals.

\section{The influence of orographic barriers on regional climate}

During the LGM, atmospheric circulation was strongly affected by ice sheets (Labeyrie et al. 2003) at both a global and regional scale. The ice megalobe which covered the northern parts of Poland and Germany (Kasprzak 2003) during the Weichselian ice sheet (Fig. 1) protruded ca. $200 \mathrm{~km}$ southward from the main ice mass. Owing to its thickness, about $800 \mathrm{~m}$ at latitude $53^{\circ}$ N (Kasprzak 2003), it severely affected the local climate. Alverson (2003) suggested that, over ice sheets, there were situations favourable for anticyclonic circulation and planetary waves (atmospheric Rossby waves) were enhanced; this made the air drier and colder in the forefield. However, in situations of temporary low-pressure above the ice cap, the intensity of cold air release could be even stronger (Thorson \& Bender 1985). Naturally, regional effects associated with the smaller (smaller, that is, in comparison to ca. $2 \mathrm{~km}$ high ice cap over the Scandinavia) orographic barriers like protruding ice megalobes (e.g., this in Poland and Germany) would probably modify the mesoscale air mass flow, including widespread development of katabatic winds, as is observed at present in the case of the wintertime Antarctic surface wind field (Parish \& Cassano 2003). According to Parish \& Cassano (2003), the wind speed component of katabatic flow may be comparable with the component of pressure gradient force which plays an important role in shaping the planetary boundary layer. However, existing simulations run on mesoscale dynamical models and experiments carried out in a laboratory (Baines \& Fraedrich 1989) show that katabatic flow is quite a sensitive phenomenon, and varies considerably owing to the initial and boundary conditions, which cannot be represented well in a GCM without proper evaluation. It is known that together with other local effects associated with the Antarctic ice sheet, katabatic flow can reach as much as several kilometers per hour (in areas with relatively low surface friction values) with deviation $\mathrm{ca} .20^{\circ}-50^{\circ}$ owing to the Coriolis force (Parish \& Cassano 2003). Such research is obviously helpful in the reconstruction of the range and direction of wind fields in the marginal areas of Weichselian ice sheet. It may therefore be assumed that, during the LGM, the prevailing wind blew from the NE to E from areas at a considerable distance from the ice megalobe.

\section{EdGCM simulation results}

EdGCM simulations show that relatively high atmospheric pressure was present over the ice sheet during the whole year (Fig. 2a, 2b, 2c), with highest intensities during the winter (Fig. 2b). High pressure interfered with regional atmospheric circulation over the whole of Central Europe. Low pressure areas over southern Europe and the northern part of the Atlantic Ocean resulted in flow of air masses bearing a significant quantity of available precipitable water. The simulation contours of surface air temperature were parallel with the ice margin. The mean annual air 
temperature ranged between $-13^{\circ} \mathrm{C}$ in southern Scandinavia to a little below $0^{\circ} \mathrm{C}$ in southern Germany and Slovakia (Fig. 3a). In winters, the temperature decreased to less than $-30^{\circ} \mathrm{C}$ in southern Scandinavia, while in southern part of area of interest, it was $-15^{\circ} \mathrm{C}$ (southern Germany) to

a

Annual Sea level pressure
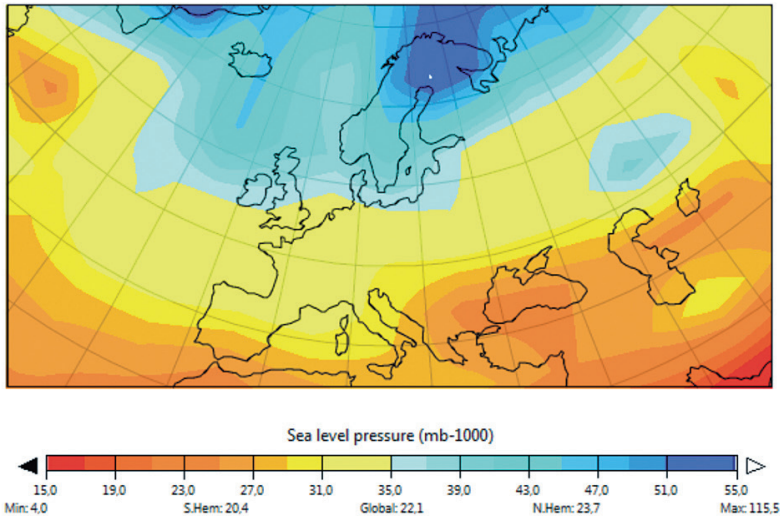

b

January Sea level pressure
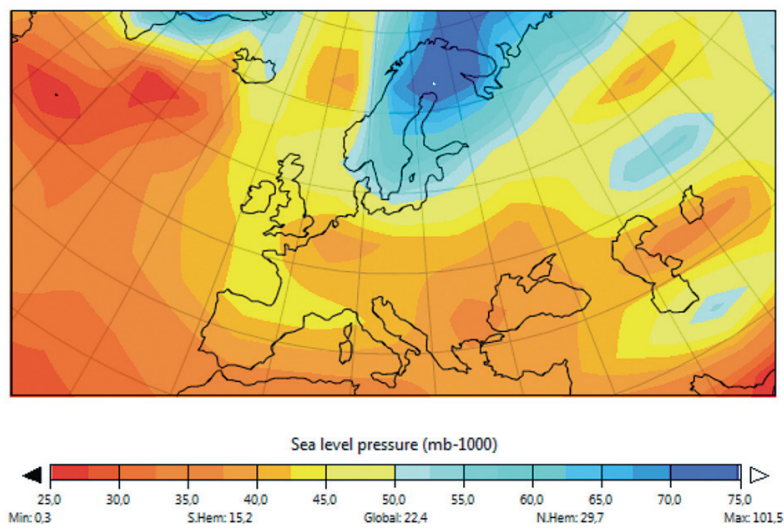

C

July Sea level pressure

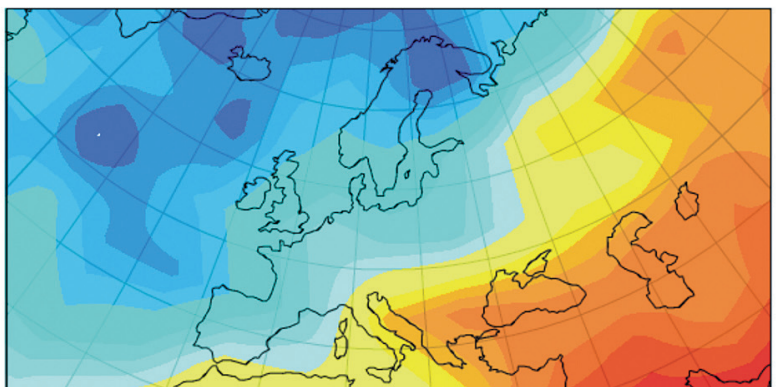

Sea level pressure ( $\mathrm{mb}-1000)$

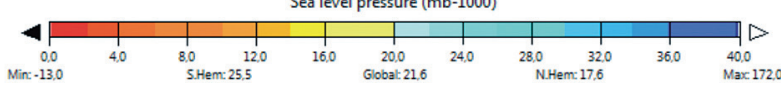

Fig. 2. Air pressure at sea level 21 ka BP for annual (a), winter (b) and summer (c) periods. Further explanation in the text $-19^{\circ} \mathrm{C}$ (Fig. 3b). During the summer seasons, temperature increased to more than $15^{\circ} \mathrm{C}$ in Ukraine, while in what is now the southern part of the Baltic Sea, it was ca. $2^{\circ} \mathrm{C}$ (Fig. 3c). There was a general increase across the whole of Central Europe.

a

Annual Surface Air Temperature (cce_Age_21 kya.1901-1910ij.nc)
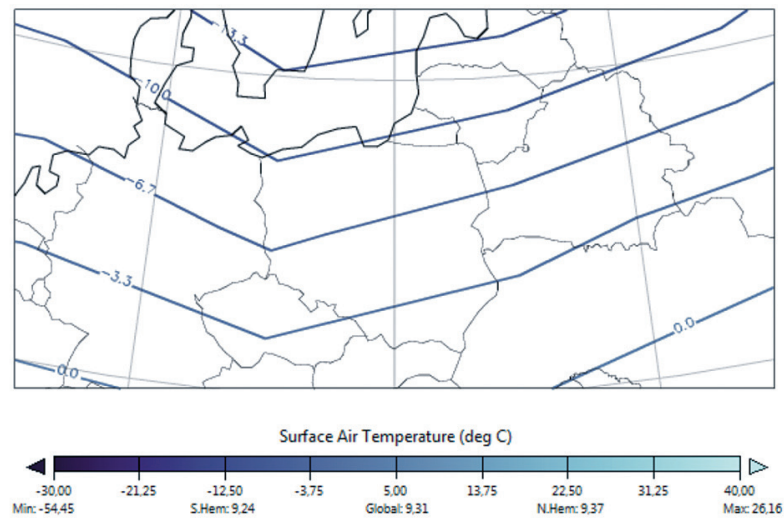

b January Surface Air Temperature (Ice_Age_21kya.1901-1910ij.nc)
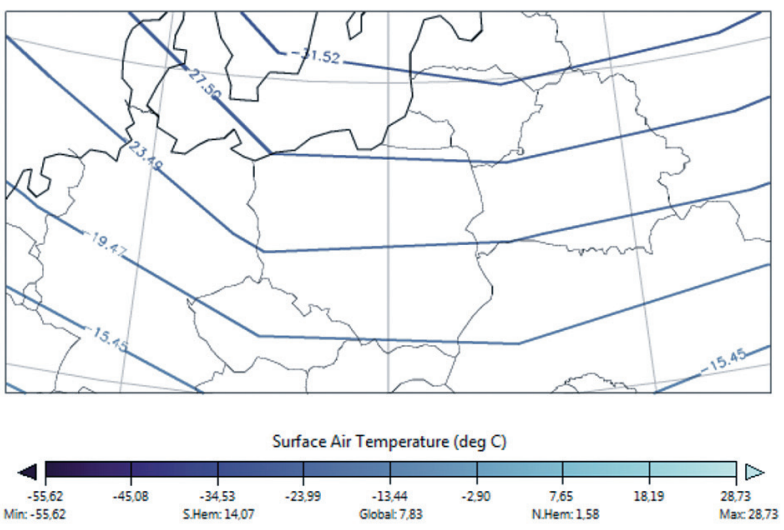

C

July Surface Air Temperature [Ic__Age_21kya.1901-1910ij.nc)
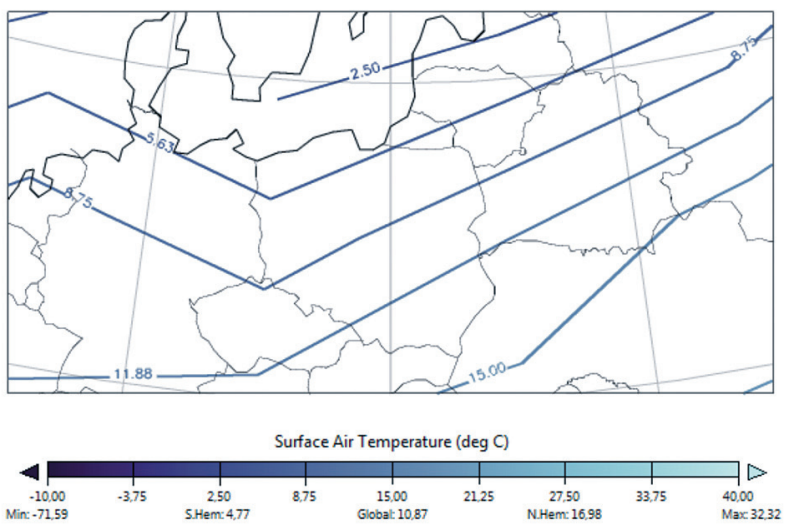

Fig. 3. Temperature isotherms $21 \mathrm{ka} \mathrm{BP}$ for annual (a), winter (b) and summer (c) periods. Further explanation in the text 
a Annual Precipitation $(\mathrm{mm} / \mathrm{yr})$

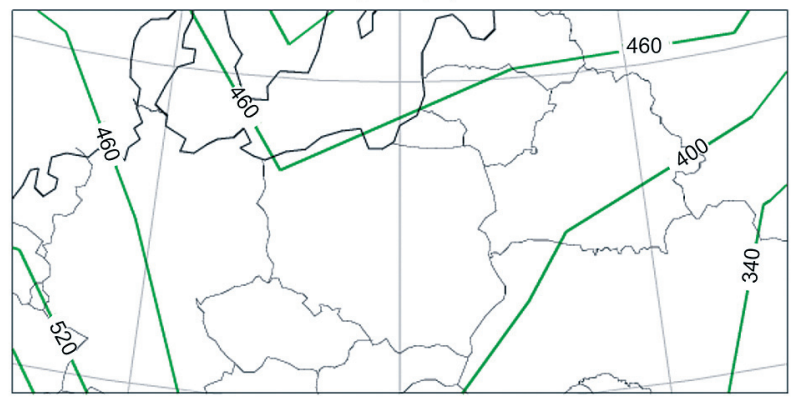

b Annual surface wind speed $(\mathrm{m} / \mathrm{s})$ and wind directions $(\rightarrow)$

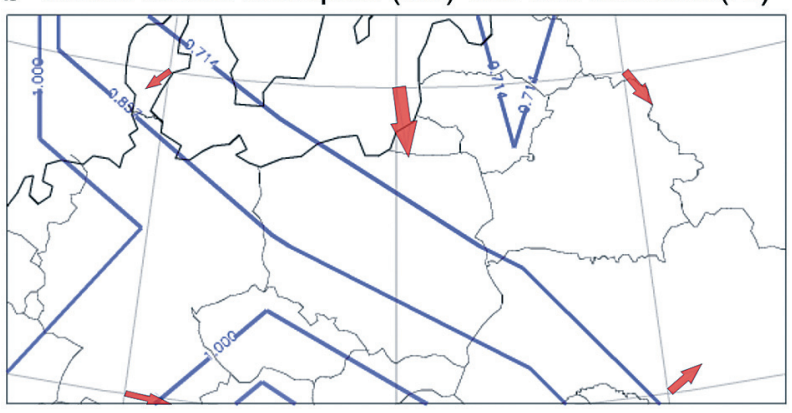

Fig. 4. a - annual precipitation amount. $\mathrm{b}$ - annual surface wind speed. Further explanation in the text

Figure 4a shows annual precipitation derived from the simulation. It is suggested that there was ca. $340-400 \mathrm{~mm} \mathrm{yr}^{-1}$ in the southern part of Ukraine to more than $460 \mathrm{~mm} \mathrm{yr}^{-1}$ in the Baltic Sea basin and Germany. The surface annual mean wind speed ranged from $0.7 \mathrm{~m} \mathrm{~s}^{-1}$ over the ice cap to $1.0 \mathrm{~m} \mathrm{~s}^{-1}$ over its forefield (Fig. $4 \mathrm{~b}$ ). Locally, in the forefield, the wind speed was probably increased by katabatic wind, caused by the flow of cold masses of air from ice-sheet plateau; however, the grid resolution of the EdGCM is too low to confirm this. Close to the ice margin, the wind blew from $\mathrm{N}$ to $\mathrm{S}$ (upper part of Fig. $4 b)$, perpendicular to the axis of the ice sheet. In southern parts of the study area (i.e., southern Germany, Czech Republic, Slovakia, Ukraine) the dominant airflow was from $\mathrm{W}$ to $\mathrm{E}$ (arrows in lower part of Fig. $4 \mathrm{~b}$ ), i.e., parallel with the ice cap.

We consider that the results of simulations, especially those for temperature and wind directions fields, are superior to some of the previous models used in the Paleoclimate Modelling Intercomparison Project for the reconstruction of climate conditions during the LGM in Central Europe (Braconnot 1999).

\section{Paleoclimatic indicator data}

With respect to Poland territory and the period between 25-15 ka BP, Goździk (1991), Kozarski (1995), Kasprzak (2003), Antczak-Górka (2005) and Dzierżek \& Stańczuk (2006) and others have tried to evaluate paleoclimates on the basis of relict geomorphological features. However, none of these has focused on the LGM (21 ka BP). In fact, very few data are available for this specific interval.

On the basis of windpolished stones investigations, Christiansen \& Svensson (1999) concluded that, during the Weichselian glaciation in Denmark at $c a$. 22-17 ka BP, the easterly paleowinds were associated with katabatic and/or zonal wind flow with anticyclonic circulation. Those winds are related to a nearby ice front, where chilled and heavy air masses flow gravitationally. Katabatic wind develops in appropriate meteorological and topographical conditions, mostly depending on: slope angle and roughness, air temperature, surface temperature, the elevational range of the cooling surface, the depth of the chilled air mass, the topography and the regional weather conditions (Thorson \& Bender 1985). Thorson \& Bender estimated the width of the katabatic wind zone as $<50 \mathrm{~km}$. Vandenberghe $e t$ al. (1999) associated the reconstructed paleowind directions in southern Sweden with anticyclonic circulation; however, establishing the relative importance of those two factors (anticyclonic and katabatic wind), is still impossible (Antczak-Górka 2005), certainly on the basis of applying the windpolished boulders criterion. Antczak-Górka (2005) speculates that the winds which shaped boulders in Polish lowlands could have been from the same direction as those which created the paleodune systems there.

On the evidence of relict dune orientation, Goździk (1991) reasoned that the mean wind direction for southern Poland was from WNW to ESE. He also concluded that, before the maximal advance of the ice sheet, aeolian activity had been stronger than during the later post-glacial period.

The climate of the Late Plenivistulian was cold and dry (Kozarski 1995) with a mean annual temperature for western Europe below $-1^{\circ} \mathrm{C}$ (Renssen et al. 2007). The differences in mean annual 
temperatures between the western and eastern parts of the ice megalobe were probably of the order of a few degrees centigrade. Kasprzak (2003) suggested $-4^{\circ} \mathrm{C}$ for western and $-9^{\circ} \mathrm{C}$ for eastern part of the ice megalobe. The climate along the southern margin of ice sheet was colder and drier toward east, reflecting the reduction of oceanic influences in this direction. Because the North Atlantic area was covered by ice, the heat flux was weaker; that, in turn, caused a reduction of temperature and lesser precipitation over Europe which, according to Kozarski (1995) could have been as low as $100 \mathrm{~mm} \mathrm{y}^{-1}$. It is also believed that, owing to orographical factors in the eastern part of the ice megalobe, the precipitation was commensurately lower, the ice megalobe having been chilled and dried from west to east.

Dzierżek \& Stańczuk (2006) reported Weichselian permafrost features (their TL data e.g. ca. 23 ka BP) in eastern Poland. They postulated a thin active layer here (about $0.5-0.7 \mathrm{~m}$ ) indicative of a severe climate. French (2007) suggested that ice wedges developed in fine-grained sediments in climates where the mean annual temperature was less than $-4^{\circ} \mathrm{C}$, and in coarse-grained ones, below $-8^{\circ} \mathrm{C}$. Kozarski (1995) and others have reported both in respect of Polish territory. The frost wedges are generally considered to have formed in a cold, dry climate (Kozarski, 1995).

\section{Conclusions}

EdGCM is usually accepted as a coarse-grid global climate model, so any results forthcoming must be regarded as broad approximations. However, we consider that the results of our simulations, especially those for temperature and wind direction fields are, in fact, more accurate than is the case in some other models used in the Paleoclimate Modelling Intercomparison Project (PMIP; Braconnot 1999) which had the specific purpose of reconstructing climate conditions during the LGM across Central Europe.

The comparison of simulated results together with selected relict geomorphological data shows:

(1) a correspondence between the conclusions about the simulated wind direction for southern-central Europe, from $\mathrm{W}$ to $\mathrm{E}$, with re- sults of Goździk's (1991) research (WNW-ESE). However, by comparison, our results for the annual average wind velocity give much smaller values. This may be a result of specific averaging (in post-processing software) derived from both: meridional and parallel wind components, which often have opposing scalar values during year. Averaging wind speed from mean values of vector components before calculating separately the magnitude of wind speed for every single month can effect in a reduction of the final result.

(2) The calculated EdGCM's mean annual temperatures for the immediate glacial forefield $\left(-3.3^{\circ} \mathrm{C}\right.$ to $\left.-6.7^{\circ} \mathrm{C}\right)$ also accord with Kasprzak's (2003) conclusion $\left(-4.0^{\circ} \mathrm{C}\right.$ to $\left.-9.0^{\circ} \mathrm{C}\right)$ as do the temperatures postulated for ice wedge cast formation (below $-4.0^{\circ} \mathrm{C}$ and $-8.0^{\circ} \mathrm{C}$ ). The simulated temperatures also show variability between western and eastern parts of Central Europe, especially in respect of the summer seasons.

(3) Only the effect of simulated precipitation values (ca. $400-460 \mathrm{~mm} \mathrm{y}^{-1}$ ) is at some variance with those postulated for the dry climate condition in Poland - ca. $100 \mathrm{~mm}$ (Kozarski 1995) or less than $250 \mathrm{~mm}$ (French 2007). The unreliability of simulated precipitation values is commonplace in respect of most of numerical climate models due to problems with parametrization and, in our case, this seems to have been greatly overestimated.

(4) High pressure areas located mostly over northern part of the Scandinavian Peninsula (Fig. $2 a, 2 b, 2 c)$ could have resulted in a regular flow of Arctic air masses derived from area of the Barents Sea; this may be the explanation for a lower amount of precipitation than simulated by our model.

(5) It is also suggested that owing to cooling and loss of humidity from the air masses lying over the ice megalobe, this barrier was high and large enough to cause significant differences in local climate between western and eastern parts of Central Europe.

To summarise: simulation results show that coarse-grid global climate model can certainly be a helpful tool in regional paleoclimate recognition. Nevertheless, it represents only a broadbrush approach and for detailed scientific purposes, especially at a local scale, it is recommended that a specially configured version of a RCM 
(Regional Climate Model) be used. However, the boundary conditions should be considered with association with relict geomorphological data as a source of surface initial condition, while GCM's simulation may be a source of information for the upper atmospheric layers.

\section{Acknowledgements}

The authors would like to thank Peter Walsh for manuscript review and Marek Ewertowski for valuable comments. Our research was financially supported by the Polish National Committee on Scientific Research (KBN) (Grant No. 0324/B/ P01/2010/39).

\section{References}

AnTCZAK-GóRKA B., 2005. Głazy rzeźbione przez wiatr jako wskaźnik różnowiekowych stref peryglacjalnych ostatniego zlodowacenia w Polsce zachodniej (Wind-polished stones as indicators of last-glaciation periglacial zones of various ages in western Poland). Wydawnictwo Naukowe UAM, Poznań.

Braconnot P., 1999. Paleoclimate Modeling Intercomparison Project (PMIP). Proceedings of the Third PMIP Workshop, World Climate Research Programme, La Huardiere, Canada.

Baines P.G. \& Fraedrich K., 1989. Topographic effects on the mean tropospheric flow patterns a round Antarctica. Journal of the Atmospheric Sciences 46: 3401-3415. DOI: 10. 1175/1520-0469(1989)046<3401:TEOTMT>2.0.CO;2.

ChANDLER M.A., RichardS S.J. \& SHOPSIN M.J., 2005. EdGCM: Enhancing climate science education through climate modelling research projects. In: Proceedings of the 85th Annual Meeting of the American Meteorological Society, 14th Symposium on Education. San Diego, CA, pp. P1.5. http:/ / edgcm.columbia.edu.

Christiansen H.H. \& Svensson H., 1999. Windpolish evidence: an important direct indicator of geomorphologically active paleo-winds. A reply to the discussion by Vanderberghe, Irsin and Renssen. Premafrost and Periglacial Processes 10: 203-204.

Dzierżek J. \& Stańczuk D., 2006. Record and paleogeographical implications of Pleistocene periglacial processes in the Drohiczyn Plateau, Podlasie Lowland (Eastern Poland). Geological Quarterly 50: 219-228.

EWERTOWSKI M., 2009. Ice-wedge Pseudomorphs and Frostcracking structures in Weichselian Sediments, CentralWest Poland. Permafrost and Periglacial Processes 20(4): 315-419. DOI: 10.1002/ppp.657.
French H.M., 2007. The Periglacial environment. Third Editions. J. Wiley and Sons, Chichester.

GoźDZIK J., 1991. Sedimentological record of aeolian processes from the Upper Plenivistulian and the turn of Pleni- and Late Vistulian in Central Poland. In: S. Kozarski (ed.). Late Vistulian (Weichselian) and Holocene Aeolian Phenomena in Central and Northern Europe. Zeitschrift für Geomorphologie, Suplement-Band 90: 51-60.

KASPRZAK L., 2003. Model sedymentacji lądolodu vistuliańskiego na Nizinie Wielkopolskiej (Model of the Vistulian ice-sheet sedimentation in the Wielkopolska Lowland). Wydawnictwo Naukowe UAM, Poznań.

KozARSKI S., 1995. Deglaciation of nortwestern Poland: Environmental conditions and geosystem transformation 20-10 ka BP. Dokumentacja Geograficzna 1: 82 p.

Kutzbach J.E. \& Webb III T., 1993. Conceptual Basis for Understanding Lake-Quaternany Climates. In: H.E. Wright, Jr.J.E. Kutzbach, T. Webb III, W.F. Ruddiman, F.A., Street-Perrot \& P.J. Bartlein (eds). Global Climates since the Last Glacial Maximum. University of Minnesota Press, Minneapolis: 5-11.

Labeyrie L., Cole J., Alverson K. \& Stocker T., 2003. The History of Climate Dynamics in the Late Quaternary. In: K. Alverson, R.S. Bradley \& T.F. Pedersen (eds). Paleoclimate, global change and the future. Springer-Verlag, Berlin: 33-61.

Parish T. R. \& CASSANo J. J., 2003. Diagnosis of the Katabatic Wind Influence on the Wintertime Antarctic Surface Wind Field from Numerical Simulations. Monthly Weather Review 131 (6): 1128-1139. DOI: 10.1175/15200493(2003)131

Peltier W.R., 1994. Ice Age Paleotopography. Science 256: 195-201. DOI: 10.1126/science.265.5169.195

Renssen H., Kasse C., Vandenberghe J. \& Lorenz S.J. 2007. Weichselian Late Pleniglacial surface wind over northwestern and central Europe: a model comparison. Journal of Quaternary Science 22(3): 281-293. DOI: 10.1002/ jqs.1038

Rew R. K., Davis G. P. \& Emmerson S., 1993. NetCDF User's Guide, An Interface for Data Access. Version 2.3, April 1993.

THORSON R.M. \& BENDER G., 1985. Eolian deflation by ancient catabatic winds: A late Quaternary example from the north Alaska Renge. Geological Society of America Bulletin 96: 702-709. DOI: 10.1130/0016-7606(1985)96

VANDENBERGHE J., ISARIN R.F.B. \& RENSSEN H., 1999. Comments on windpolished boulders as indicators of a late Weichselian wind regime in Denmark in relation to neighbouring areas by Christiansen and Svensson [9(1): 1-21, 1998]. Premafrost and Periglacial Processes 10: 199-201. DOI: 10.1002/(SICI)1099-1530(199904/06)10:2

Yokohama Y., Lambeck K., DekKer P., Johnston P. \& FifLEDS K.L. 2000. Timing of the Last Glacial Maximum from observed sea-level minima. Nature 406: 713-716, DOI:10.1038/35021035 